\title{
Enhancement of Clostridium difficile toxin production in biotin-limited conditions
}

\author{
K. YAMAKAWA, T. KARASAWA, S. IKOMA and S. NAKAMURA \\ Department of Bacteriology, School of Medicine, Kanazawa University, Kanazawa 920, Japan
}

\begin{abstract}
The effect of biotin on toxin production by Clostridium difficile was examined in a

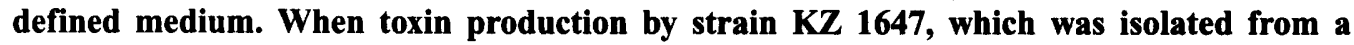
healthy adult, was examined in relation to its biotin requirement, it was found that with decreasing concentrations of biotin, bacterial growth was decreased, but production of both toxins $A$ and $B$ were remarkably increased, particularly with $0.05 \mathrm{nM}$ biotin. The time course of production of both toxins in biotin-limited conditions was similar to that in biotin-enriched conditions. The biotin effect on toxin production was also observed in 15 other strains, suggesting that the effect occurs frequently amongst toxigenic $C$. difficile strains. The biotin effect is discussed in relation to the pathogenesis of $C$. difficile colitis.
\end{abstract}

\section{Introduction}

Clostridium difficile causes pseudomembranous colitis and antibiotic-associated diarrhoea [1-4]. Toxins A and $B$ produced by the bacterium are major pathogenic factors [4-6], and although these toxins are now well characterised, the nutritional requirements for toxin production are still unclear. Haslam et al. [7] investigated the effect of amino acids on toxin production by $C$. difficile in a defined medium. On the basis of their findings, we recently designed a defined medium composed of a limited number of amino acids, in which $C$. difficile produced both toxins in fairly high amounts [8]. In the course of a study of vitamin requirements for toxin production in this medium, a unique phenomenon was encountered, such that the toxins were produced in much higher amounts in a limited supply of biotin. This paper describes the effect of biotin on toxin production by $C$. difficile.

\section{Materials and methods}

\section{Bacterial strains}

Sixteen toxigenic $C$. difficile strains were used. These strains were isolated in this laboratory from healthy adults or patients with antibiotic-associated diarrhoea [9]. Strain KZ 1647 from a healthy adult was used in most studies for the examination of the effect of biotin on toxin production.

Received 15 March 1995; revised version accepted 10 July 1995.

Corresponding author: S. Nakamura.

\section{Preparation of defined medium}

A defined medium $(6 \times$ MADM) [8], was used with some modifications (Table 1): thiamine, nicotinamide, riboflavin, aminobenzoic acid, folic acid and vitamin $\mathrm{B}_{12}$ were omitted as it was found that these vitamins had no effect on growth [10]. The original concentration of biotin was $50 \mathrm{nM}(12.2 \mu \mathrm{g} / \mathrm{L})$ in this defined medium. The medium was sterilised by membrane filtration (Millex-HA, pore size, $0.45 \mu \mathrm{m}$; Nihon Millipore, Yonezawa, Japan) and distributed in $10-\mathrm{ml}$ amounts in test tubes $(15 \times 160 \mathrm{~mm})$ flushed with oxygen-free gas $\left(\mathrm{H}_{2} \quad 10 \%, \mathrm{CO}_{2} \quad 10 \%, \mathrm{~N}_{2} 80 \%\right)$. The tubes were then stoppered with rubber stoppers [8].

\section{Inoculation and incubation}

Ten $\mathrm{ml}$ of the defined medium containing $50 \mathrm{nM}$ biotin were inoculated with $0.1 \mathrm{ml}$ of liver-broth culture that had been incubated for $24 \mathrm{~h}$ at $37^{\circ} \mathrm{C}$, and were then incubated for $16 \mathrm{~h}$ at $37^{\circ} \mathrm{C}$. The culture was diluted 1000 -fold in pre-reduced saline and $0.1 \mathrm{ml}$ of the diluted culture was inoculated into test media. The carry-over of biotin into the test medium was $<0.0005 \mathrm{nM}$. The inoculated media were incubated at $37^{\circ} \mathrm{C}$ in anaerobic conditions $\left(\mathrm{H}_{2} 10 \%, \mathrm{CO}_{2} 10 \%, \mathrm{~N}_{2}\right.$ $80 \%$ ). Duplicate cultures were performed for each test and mean values of the duplicate tests are presented in the Results in all cases. Culture supernates sterilised through a membrane (Millex-HV, pore size, $0.45 \mu \mathrm{m}$; Nihon Millipore) were used for the toxin assays.

\section{Bacterial growth}

Bacterial growth was determined by measuring the 
Table 1. Composition of defined medium for $C$. difficile

\begin{tabular}{lclc}
\hline Component & Concentration & Component & Concentration \\
\hline Amino acids & $(\mathrm{g} / \mathrm{L})$ & Vitamins & $(\mu \mathrm{g} / \mathrm{L})$ \\
Tryptophan & 0.6 & Ca-D-pantothenate & 1000 \\
Methionine & 1.2 & Pyridoxine & 1000 \\
Valine & 1.8 & Biotin & 12.2 \\
Isoleucine & 1.8 & & \\
Proline & 1.8 & $\mathrm{Minerals}^{2}$ & $(\mathrm{mg} / \mathrm{L})$ \\
Leucine & 2.4 & $\mathrm{KH}_{2} \mathrm{PO}_{4}$ & 900 \\
Cysteine & 0.5 & $\mathrm{Na}_{2} \mathrm{HPO}_{4}$ & 5000 \\
Glycine & 0.2 & $\mathrm{NaCl}_{4}$ & 900 \\
Threonine & 0.4 & $\mathrm{CaCl} 2.2 \mathrm{H}_{2} \mathrm{O}$ & 26 \\
& $(\mathrm{~g} / \mathrm{L})$ & $\mathrm{MgCl}_{2} \cdot 6 \mathrm{H}_{2} \mathrm{O}$ & 20 \\
Glucose & 2.0 & $\mathrm{MnCl}_{2} \cdot 4 \mathrm{H}_{2} \mathrm{O}$ & 10 \\
& & $\left.\mathrm{NH}_{4}\right)_{2} \mathrm{SO}_{4}$ & 40 \\
& & $\mathrm{FeSO}_{4} \cdot 7 \mathrm{H}_{2} \mathrm{O}$ & 4 \\
& & $\mathrm{CoCl}_{2} \cdot 6 \mathrm{H}_{2} \mathrm{O}$ & 1 \\
& & $\mathrm{NaHCO}_{3} \mathrm{O}$ & 5000 \\
\hline
\end{tabular}

optical density of cultures at $560 \mathrm{~nm}$ with a Spectronic 20A spectrophotometer (Shimadzu, Kyoto, Japan).

\section{Toxin assay}

Toxin A concentration was determined by the direct sandwich enzyme-linked immunosorbent assay (ELISA) [11]. Male Japanese white rabbits were immunised with highly purified toxin A from $C$. difficile strain VPI 10463 as described by Kamiya et al. [12]. IgG antibody to toxin A was purified from immune serum by BioRad Protein MAPS II (BioRad Laboratories, Richmond, CA, USA) and used in the ELISA. The minimum concentration of toxin A measurable in this assay was $10 \mathrm{ng} / \mathrm{ml}$. Toxin B activity was determined by a conventional microtitration plate assay against baby hamster kidney cells [9]. After two-fold serial dilution of culture filtrates, $50 \mu \mathrm{l}$ of each diluted sample were added to the cells. The reciprocal of the highest dilution resulting in $100 \%$ cell rounding after incubation for $24 \mathrm{~h}$ was used as the number of cytotoxic units $(\mathrm{CU}) / 50 \mu \mathrm{l}$ of sample.

For the assay of intracellular toxins, $10 \mathrm{ml}$ of a culture were centrifuged and the cells were washed twice with phosphate-buffered saline, $\mathrm{pH}$ 7.2. The cells were suspended in buffer to the original volume and sonicated for $5 \mathrm{~min}$ with a Tomy ultrasonic vibrator (mode UR-200P, 20 kilocycles; Tomy Seiko, Tokyo, Japan). The bacterial debris was removed by centrifugation at $12000 \mathrm{~g}$ for $10 \mathrm{~min}$, and the supernate was filtered through a Millex-HV membrane and assayed for the toxins.

\section{Results}

\section{Concentration of biotin and toxin production}

Bacterial growth and toxin production were examined with $C$. difficile strain $\mathrm{KZ} 1647$ at concentrations of $0.00005,0.0005,0.005,0.05,0.5,5$ and $50 \mathrm{nM}$ biotin. Bacterial growth was measured over an incubation period of 5 days and the toxicity in culture supernates was measured at 5 days. Bacterial growth was maximal after incubation for 1.5 days at biotin concentrations of 50,5 and $0.5 \mathrm{nM}$ and for 2 days at concentrations of $\leqslant 0.05 \mathrm{nM}$ (Fig. 1). The maximum $\mathrm{OD}_{560}$ value during incubation was highest $(0.48)$ at a concentration of $50 \mathrm{nM}$ biotin and decreased with the decreasing biotin concentrations; the maximum $\mathrm{OD}_{560}$ was $<0.1$ at concentrations of $\leqslant 0.005 \mathrm{nM}$. On the other hand, toxin production was remarkably increased, when the concentration of biotin was reduced to $0.05 \mathrm{nM}$ (onethousandth of the original concentration) (Fig. 2), when the maximum $\mathrm{OD}_{560}$ value was $0.17, c$. one-third of that at $50 \mathrm{nM}$. Toxin production increased 35 -fold for toxin $\mathrm{A}$ and 64-fold for toxin $\mathrm{B}$; the amounts of toxin $A$ at $50 \mathrm{nM}$ and $0.05 \mathrm{nM}$ biotin were $54 \mathrm{ng} / \mathrm{ml}$ and $1880 \mathrm{ng} / \mathrm{ml}$, respectively, and the toxin $\mathrm{B}$ activities were $512 \mathrm{CU} / 50 \mu \mathrm{l}$ and $32768 \mathrm{CU} / 50 \mu \mathrm{l}$, respectively. When the concentration of biotin decreased from 0.05 to $0.005 \mathrm{nM}$, the toxin production markedly decreased, but even at $0.00005 \mathrm{nM}$ biotin, toxin production (toxin

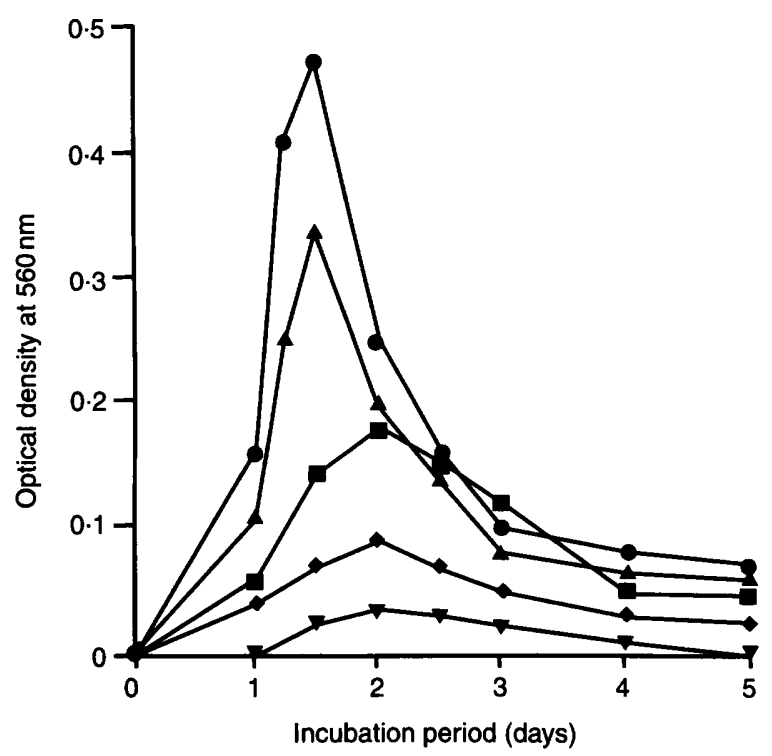

Fig. 1. Bacterial growth of $C$. difficile $\mathrm{KZ} 1647$ at various concentrations of biotin. Biotin concentration: $0,50 \mathrm{nM} ; \Delta, 0.5 \mathrm{nM} ; \square, 0.05 \mathrm{nM} ; \bullet, 0.005 \mathrm{nM} ; \nabla$, $0.00005 \mathrm{nM}$. Growth curves at 5 and $0.0005 \mathrm{nM}$ biotin are omitted from the figure to avoid complexity. Each point represents the mean value of duplicate tests. 


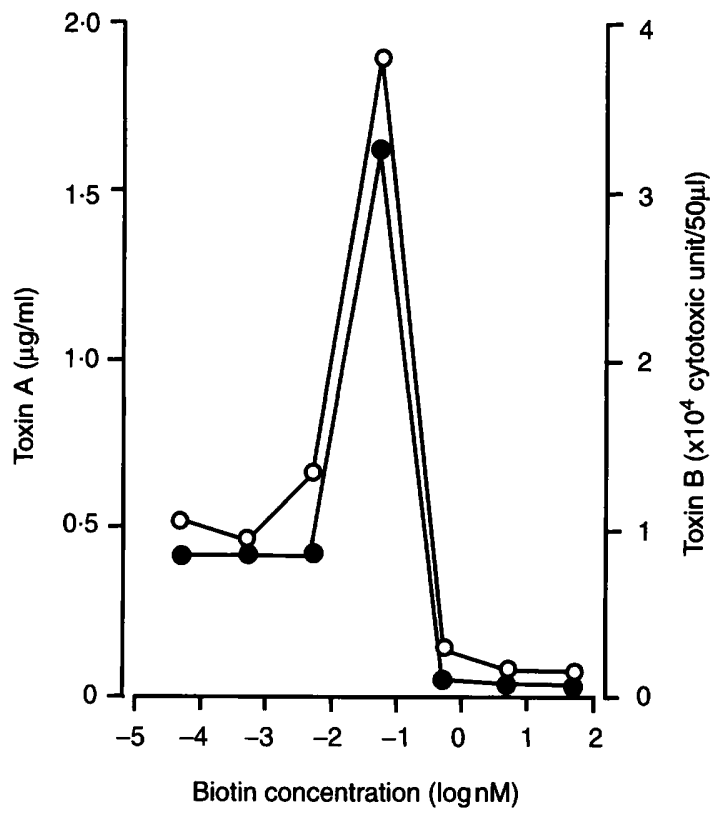

Fig. 2. Toxin production of $C$. difficile $\mathrm{KZ} 1647$ at various concentrations of biotin. $O$, toxin $A ; \boldsymbol{O}$, toxin $B$.

A, $495 \mathrm{ng} / \mathrm{ml}$; toxin $\mathrm{B}, 8192 \mathrm{CU} / 50 \mu \mathrm{l})$ was much higher than that at $50 \mathrm{nM}$.

\section{Incubation period and toxin production}

The relationship between incubation period and toxin production was examined with strain $\mathrm{KZ} 1647$ at the concentrations of 0.05 and $50 \mathrm{nM}$ biotin. The amounts of toxins A and B were measured in cultures harvested 1-5 days after inoculation. The pattern of toxin production at $0.05 \mathrm{nM}$ biotin was similar to that at $50 \mathrm{nM}$ biotin. At either 0.05 or $50 \mathrm{nM}$ biotin, neither toxin was detected at 1 day, both appeared in 2 days, and reached maximum values after incubation for 4 days (Fig. 3). During the incubation period when the toxin production was increasing, bacterial growth was declining as seen in Fig. 1.

Titres of toxins A and B in sonicated cell extracts were consistently low during incubation with either 0.05 or $50 \mathrm{nM}$ biotin: the maximum values of toxins $A$ and $B$ at $0.05 \mathrm{nM}$ biotin were $170 \mathrm{ng} / \mathrm{ml}$ ( 3 days) and $2048 \mathrm{CU} / 50 \mu \mathrm{l}$ ( 3 days), respectively, and those values at $50 \mathrm{nM}$ biotin were $14 \mathrm{ng} / \mathrm{ml}$ ( 3 days) and $128 \mathrm{CU} /$ $50 \mu \mathrm{l}$ ( 3 days), respectively.

\section{Toxin production by other $C$. difficile strains in biotin-limited defined medium}

Toxin production in the defined medium with $0.05 \mathrm{nM}$ biotin after incubation for 5 days was tested for another 15 strains in comparison to that in the defined medium with $50 \mathrm{nM}$ biotin. All 15 strains produced much more toxin $A$ at $0.05 \mathrm{nM}$ biotin than at $50 \mathrm{nM}$ biotin (Fig. 4). Toxin A production increased 2-63-fold (average, 21fold). The increase in toxin $B$ production was comparable to that of toxin $\mathrm{A}$.

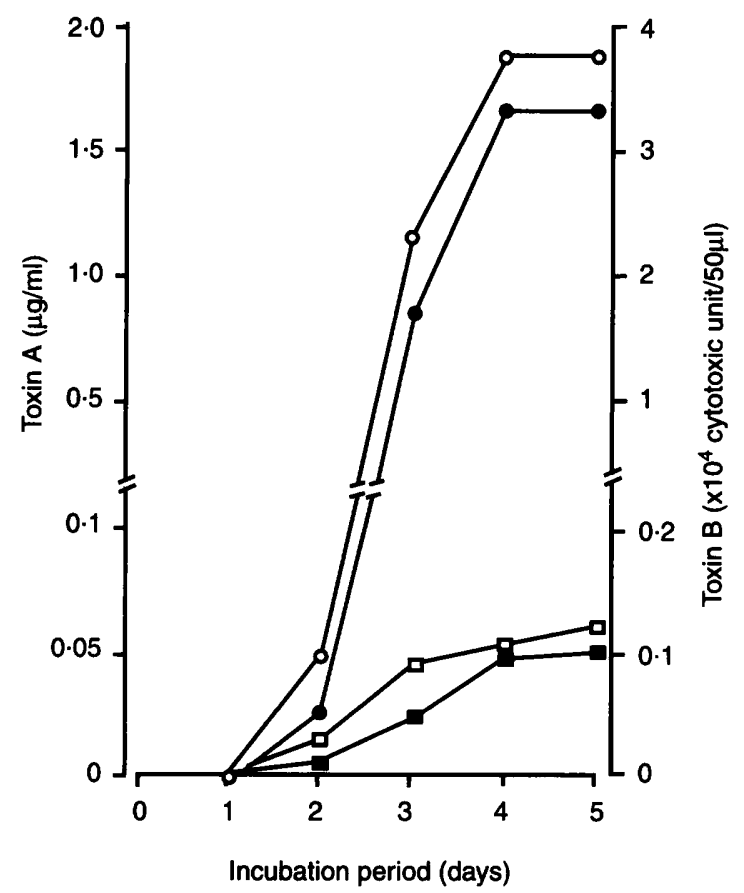

Fig. 3. Time course of toxin production by $C$. difficile KZ 1647 at biotin concentrations of $0.05 \mathrm{nM}(O, O)$ and $50 \mathrm{nM}(\square, \square) . \bigcirc, \square$, toxin A;,$\square$, toxin B. Each point represents the mean value of duplicate tests.

\section{Discussion}

Nutrients affect the toxin production by pathogenic bacteria [13]. In $C$. difficile, lack of essential amino acids suppresses both bacterial growth and toxin production $[7,8]$. The effect of biotin on toxin production shown in this study is unique in contrast

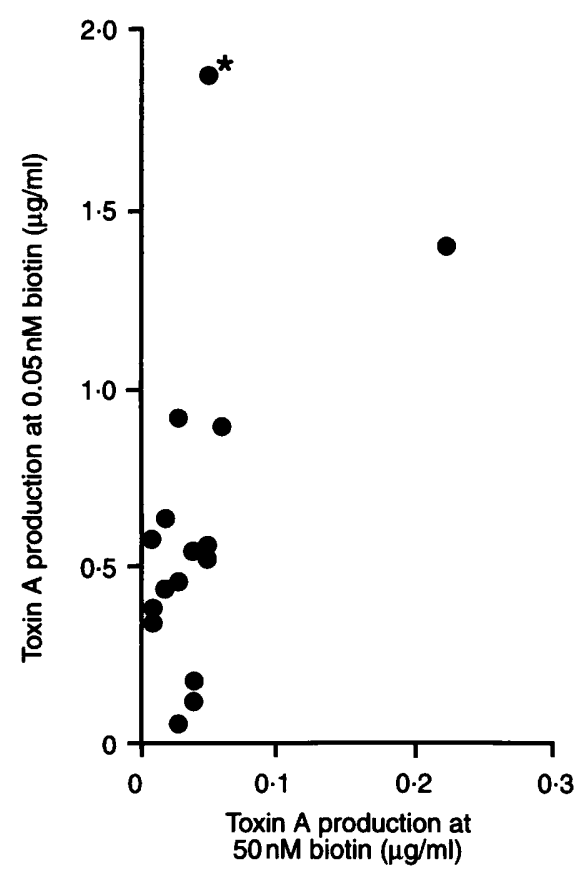

Fig. 4. Toxin A production by $15 \mathrm{C}$. difficile strains grown with $0.05 \mathrm{nM}$ biotin compared to that at $50 \mathrm{nM}$ biotin. ${ }^{*} C$. difficile $\mathrm{KZ} 1647$. Each point represents mean value of duplicate tests. 
to the effect of amino acids mentioned above. When the concentration of biotin, which is essential for growth [10], was reduced, growth decreased as expected, whilst toxin production greatly increased, particularly at $0.05 \mathrm{nM}$ biotin, one-thousandth of the optimal concentration for growth. Considering that titres of toxins A and B in sonicated cell extracts were low at either 0.05 or $50 \mathrm{nM}$, compared with those in culture supernates, it seems that the enhancement of toxin production in the biotin-limited conditions results from an enhancement of toxin synthesis rather than of toxin release from the cells. Cytotoxin (toxin B) production by $C$. difficile in an ordinary complex culture medium is also suggested to be associated not with the release of the toxin during cell lysis but with de novo synthesis [14].

Toxin production by $C$. difficile is stimulated by exposure to subinhibitory concentrations of antibiotics, higher incubation temperatures and high oxidationreduction potential [15-18], suggesting that some stresses on the growth stimulate toxin production. From this standpoint, biotin insufficiency seems to be one of the important stresses leading to the enhancement of toxin production. Furthermore, it is possible that intermediates in the metabolic pathways involving biotin-dependent enzymes may play an important role in the expression of toxin genes, as biotin is a prosthetic group of certain carboxylation-catalysing enzymes [19]. Genes encoding toxins A and B have been cloned [20,21], yet the molecular basis of gene expression is still unknown. The study of the mechanism of the biotin effect is now in progress in this laboratory.

The present study also showed that the biotin effect occurred in all strains tested, suggesting that it is a general phenomenon amongst toxigenic strains. Therefore, considering that biotin is synthesised by members of the bacterial flora in the human intestine $[22,23]$, we postulate that the biotin effect may play an important role in the development of colitis. When antibiotics disturb the normal flora, biotin-limited conditions may be produced in the intestine that accelerate toxin production by $C$. difficile and cause colitis. This may partly explain the efficacy of bacteriotherapy for chronic relapsing $C$. difficile diarrhoea [24]. Furthermore, we expect that direct 'biotin treatment' will open a new window to control the disease from both a prophylactic and therapeutic aspect. In this respect it might be necessary to examine the amount of biotin in the faeces of patients with $C$. difficile colitis. It would also be of interest to determine whether the biotin effect occurs in other toxigenic bacteria that cause intestinal infection.

This work was supported in part by a Grant-in-Aid for Scientific Research from the Ministry of Education, Science and Culture of Japan.

\section{References}

1. George WL, Sutter VL, Goldstein EJC, Ludwig SL, Finegold SM. Aetiology of antimicrobial-agent-associated colitis. Lancet 1978; 1: 802-803.

2. Larson HE, Price AB, Honour P, Borriello SP. Clostridium difficile and the aetiology of pseudomembranous colitis. Lancet 1978; 1: 1063-1066.

3. Bartlett JG, Chang YW, Gurwith M, Gorbach SL, Onderdonk AB. Antibiotic-associated pseudomembranous colitis due to toxin-producing clostridia. $N$ Engl J Med 1978; 298: 531-534.

4. Lyerly DM, Krivan HC, Wilkins TD. Clostridium difficile: its disease and toxins. Clin Microbiol Rev 1988; 1: 1-18.

5. Sullivan NM, Pellett S, Wilkins TD. Purification and characterization of toxins $\mathbf{A}$ and $\mathbf{B}$ of Clostridium difficile. Infect Immun 1982; 35: 1032-1040.

6. Banno $\mathrm{Y}$, Kobayashi $\mathrm{T}$, Kono $\mathrm{H}$, Watanabe $\mathrm{K}$, Ueno $\mathrm{K}$, Nozawa Y. Biochemical characterization and biologic actions of two toxins (D-1 and D-2) from Clostridium difficile. Rev Infect Dis 1984; 6 Suppl 1: S11-S20.

7. Haslam SC, Ketley JM, Mitchell TJ, Stephen J, Burdon DW, Candy DCA. Growth of Clostridium difficile and production of toxins $\mathrm{A}$ and $\mathrm{B}$ in complex and defined media. $J \mathrm{Med}$ Microbiol 1986; 21: 293-297.

8. Yamakawa K, Kamiya S, Meng XQ, Karasawa T, Nakamura S. Toxin production by Clostridium difficile in a defined medium with limited amino acids. $J$ Med Microbiol 1994; 41: 319-323.

9. Nakamura S, Mikawa M, Nakashio $\mathrm{S}$ et al. Isolation of Clostridium difficile from the feces and the antibody in sera of young and elderly adults. Microbiol Immunol 1981; 25: 345351.

10. Karasawa T, Ikoma S, Yamakawa K, Nakamura S. A defined growth medium for Clostridium difficile. Microbiology 1995; 141: $371-375$.

11. Redmond SC, Ketley JM, Mitchell TJ, Stephen J, Burdon DW, Candy DCA. Detection of Clostridium difficile enterotoxin (toxin $\mathrm{A}$ ) by ELISA and other techniques. In: Collins $\mathrm{CH}$, Grange JM (eds) Isolation and identification of microorganisms of medical and veterinary importance. Society of Applied Bacteriology, Technical series No. 21. London, Academic Press. 1985: 237-250.

12. Kamiya S, Reed PJ, Borriello SP. Purification and characterisation of Clostridium difficile toxin A by bovine thyroglobulin affinity chromatography and dissociation in denaturing conditions with or without reduction. J Med Microbiol 1989; 30: 69-77.

13. Mekalanos JJ. Environmental signals controlling expression of virulence determinants in bacteria. J Bacteriol 1992; 174: 1-7.

14. Kamiya $S$, Ogura $H$, Meng $X Q$, Nakamura $S$. Correlation between cytotoxin production and sporulation in Clostridium difficile. J Med Microbiol 1992; 37: 206-210.

15. George RH, Johnson M, Youngs D, Burdon DW. Induction of Clostridium difficile toxin by antibiotics. Proceedings of the 11 th International Congress of Chemotherapy and 19th Interscience Conference on Antimicrobial Agent and Chemotherapy, 1979: 955-956.

16. Honda T, Hernadez I, Katoh T, Miwatani T. Stimulation of enterotoxin production of Clostridium difficile by antibiotics. Lancet 1983; 1: 655 .

17. Nakamura S, Mikawa M, Tanabe N, Yamakawa K, Nishida S. Effect of clindamycin on cytotoxin production by Clostridium difficile. Microbiol Immunol 1982; 26: 985-992.

18. Onderdonk AB, Lowe BR, Bartlett JG. Effect of environmental stress of Clostridium difficile toxin levels during continuous cultivation. Appl Environ Microbiol 1979; 38: 637-641.

19. Gottschalk G. Bacterial metabolism, 2nd edn. New York, Springer-Verlag. 1986.

20. Dove $\mathrm{CH}$, Wang S-Z, Price SB et al. Molecular characterization of the Clostridium difficile toxin A gene. Infect Immun 1990; 58: $480-488$.

21. Johnson JL, Phelps C, Barroso L, Roberts MD, Lyerly DM, Wilkins TD. Cloning and expression of the toxin $\mathrm{B}$ gene of Clostridium difficile. Curr Microbiol 1990; 20: 397-401.

22. Mickelsen $O$. Intestinal synthesis of vitamins in the nonruminant. Vitam Horm 1956; 14: 1-95.

23. Ohsugi M, Imanishi $Y$, Teraoka $T$, Nishimura $K$, Nakao $S$. Biosynthesis of biotin-vitamers by family Enterobacteriaceae. $J$ Nutr Sci Vitaminol 1990; 36: 447-56.

24. Bowden TA, Mansberger AR, Lykins LE. Pseudomembranous enterocolitis: mechanism of restoring floral homeostasis. $\mathrm{Am}$ Surg 1981; 47: 178-83. 